\title{
WHAT DO WE KNOW ABOUT ALIMENTARY TRACT DUPLICATIONS IN CATS?
}

(O que sabemos sobre duplicações de trato gastrointestinal em gatos?)

\author{
Julia Elia da Silva Paranhos ${ }^{1}$ https://orcid.org/0000-0002-7623-4036, Ylla Castro de Macedo', Marianna Bretas \\ de Araújo르. Gabriel Nogueira Brugger Teixeira ${ }^{1}$, Tábata Maués ${ }^{1}$ https://orcid.org/0000-0002-8890-608X, Márcia \\ Carolina Salomão Santos ${ }^{1}$
}

1Universidade Federal Fluminense (UFF), Niterói, Rio de Janeiro, Brasil; República Animal Clínica Veterinária, Rio de Janeiro, Rio de Janeiro, Brasil

*Corresponding author: juliaelia@id.uff.br

ABSTRACT: We constructed a scoping review of alimentary tract duplications in cats to overview its occurrence. Inclusion criteria were determined by reviewing case reports on histologically confirmed gastrointestinal duplications, including one case description of a cat diagnosed with a duodenal duplication cyst at our institution. Thirteen gastrointestinal duplication cases were analyzed, being that one animal had a bi-focal duplication, totalizing fourteen duplications. Variables considered were age, sex, breed, presenting features, anatomic location, morphology, presence of luminal communication, malignant transformation, and recurrence. About $62 \%(n=8 / 13)$ of cats affected were between 4 months to 2 years old. No sex predisposition was observed and breed and presenting features were variable. Duodenal duplications corresponded to $36 \%$ ( $n=$ 5/14). Cystic duplications with no lumen communication accounted for $93 \%(n=13 / 14)$. One duplication was neoplastic and recurrence rate of gastrointestinal duplications amongst cats was $15 \%(n=2 / 13)$. Progression to obstruction, bleeding and malignant transformation have been described in humans and cats due to gastrointestinal duplications. Considering the importance and the diagnostic challenge of this affection, we concluded that the small animal practitioner should not overlook alimentary tract duplications in the differential diagnosis of young cats with chronic vomiting and cystic intestinal masses.

Key words: enteric duplication; feline; gastroenterology; intestine; ultrasound.

RESUMO: O presente trabalho trata-se de uma revisão de escopo de duplicações de trato gastrointestinal em gatos. Os critérios de inclusão foram determinados pela revisão de relatos de caso de duplicações gastrointestinais confirmadas por exame histopatológico, incluindo-se também neste trabalho um caso de um felino diagnosticado com duplicação cística duodenal em nossa instituição. Treze casos de 
duplicações gastrointestinais foram analisados, sendo que um animal possuía uma duplicação bifocal, totalizando, portanto, quatorze duplicações. As variáveis consideradas foram idade, sexo, raça, sintomatologia, localização anatômica, morfologia, presença de comunicação luminal, progressão para malignidade e recorrência. Aproximadamente $62 \%(n=8 / 13)$ dos gatos afetados apresentavam entre 4 meses a 2 anos de idade. Não foi observada predisposição quanto ao sexo, enquanto raça e sintomatologia variaram. Duplicações duodenais corresponderam a 36\% $(n=5 / 14)$. Duplicações císticas sem comunicação luminal 93\% $(n=13 / 14)$. Uma duplicação evoluiu para neoplasia e a recorrência de duplicações gastrointestinais entre os gatos foi de $15 \% \quad(n=2 / 13)$. Evolução para obstrução, hemorragias e malignidade já foram descritas em humanos e gatos como consequência de duplicações gastrointestinais. Considerando a importância e o desafio diagnóstico desta afecção, conclui-se que o clínico veterinário de pequenos animais deve considerar as duplicações de aparelho digestivo no diagnóstico diferencial de gatos jovens com vômitos crônicos e massas císticas intestinais.

Palavras-chave: duplicação intestinal, felinos, gastroenterologia, intestino, ultrassonografia.

\section{INTRODUCTION}

Alimentary tract duplications are uncommon congenital disorder that can occur in variable anatomic sites and demand for treatment complete excision whenever possible (Radlinsky et al., 2005). Even though duplications are considered benign lesions, malignant transformation has been reported in cats (Hobbs et al., 2015).

Clinical signs are usually non-specific, and cats can even be asymptomatic (Radlinsky et al., 2005). Vomiting, anorexia, digestive obstruction, rectal prolapse and respiratory signs (due to oesophageal cyst) have been reported (Kershaw et al., 2008; Parry-Smith et al., 2008; Kook et al., 2010; Bernardé et al., 2014; Hobbs et al., 2015; Agut et al., 2017; Kramer et al., 2017; Carbonell Buj et al., 2020). Image diagnostic techniques are required to characterize lesion morphology with emphasis on ultrasound examination - US (Nebot et al., 2018) and histological evaluation is essential to avoid misdiagnosis (Hwang et al., 2017). Most cases have excellent prognosis since surgical excision is usually curative (Parry-Smith et al., 2008).

In veterinary literature, reports of alimentary tract duplications are scarce. Herein, we aimed to construct a scoping review of data collected from the published literature of feline gastrointestinal duplications cases, adding one case of a duodenal duplication cyst diagnosed at our institution, the first Latin America case description, to overview the occurrence of this affection in cats.

Archives of Veterinary Science, v.26, n.1, p. 104-114, 2021. 


\section{CASE DESCRIPTION}

\section{Presentation}

A 2-year-old male spayed shorthair cat, negative for FIV and FeLV, weighing $4.0 \mathrm{~kg}$, was presented to primary veterinary care with a one-week history of daily emesis. History and presenting signs

A previous abdominal ultrasound had been performed due to emesis history, revealing a cystic-like mass adhered to the duodenum. Symptomatic treatment was prescribed on attempt to reduce emesis clinical sign, consisting of oral administration of antiemetic drugs (ondansetron $0.5 \mathrm{mg} / \mathrm{kg}$ TID 5 days) and proton pump inhibitors (omeprazole $1.0 \mathrm{mg} / \mathrm{kg}$ BID 5 days). Despite complete remission of clinical signs, the animal was referred to the Veterinary Teaching Hospital (HUVET) of Universidade Federal Fluminense for further diagnostic investigation and resolution.

Physical and lab evaluation

On presentation at HUVET, physical examination revealed no abnormality except for mild epigastric pain. Complete blood count and a serum biochemical profile did not evidence alterations.

\section{Other diagnostic assessments}

A second abdominal ultrasound demonstrated a round cystic structure with $1.02 \mathrm{~cm}$ (length) $\times 1.00 \mathrm{~cm}$ (width) $\times 1.17 \mathrm{~cm}$ (height) dimensions in the antimesenteric border of descending duodenum, near the cranial flexure. Cystic wall was thick and double-wall sign was present, with hyperechoic inner layer and an outer hypoechoic layer. Also, the cyst had anechoic content (Figure 1a). The architecture of intestinal wall layers was preserved and there were no signs of cyst communication with the intestinal lumen. Furthermore, there was near mesenteric fat tissue alteration. Cranial to the mass, a well-defined hyperechoic area was observed containing small tubular formations. Altogether, ultrasound diagnostic was compatible with duplication cyst and differential diagnosis considered were type I choledochal cyst; abscess; and pancreatic pseudocyst. Abdominal ultrasound recheck after 9 days revealed cystic enlargement with $2.03 \mathrm{~cm}$ (length) $\times 1.00 \mathrm{~cm}$ (width) $\times 1.04 \mathrm{~cm}$ (height) (Figure 1b). 


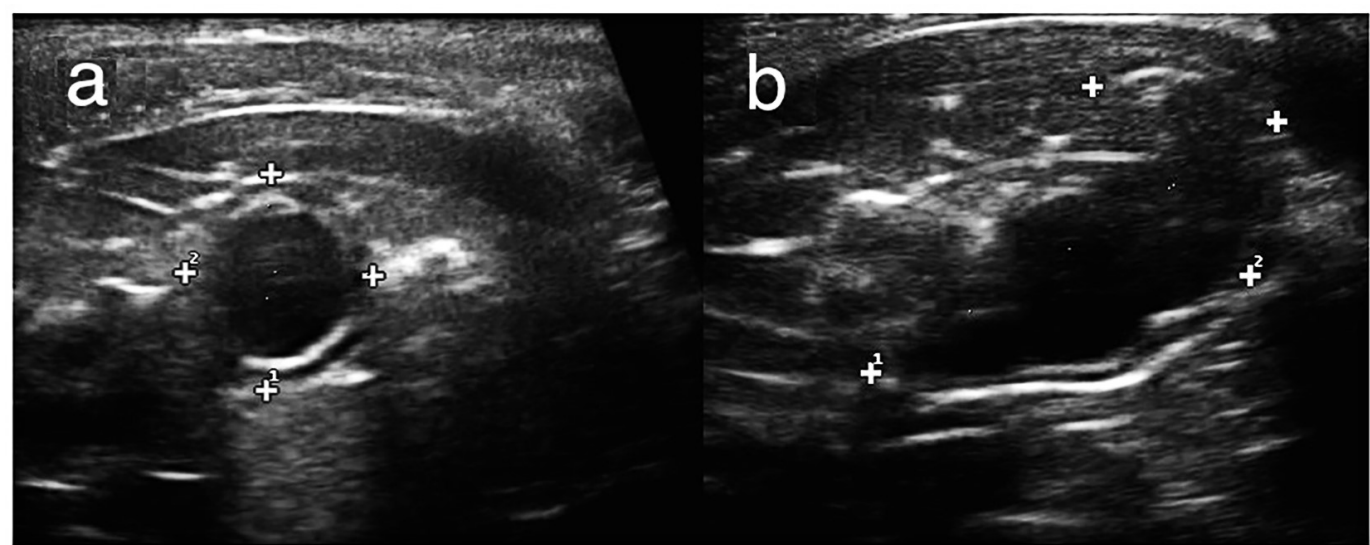

Figure 1 - Ultrasound image of a cyst adjacent to the antimesenteric border of the duodenum in a transverse (a) and longitudinal plane (b). Thickened wall and presence of double-wall sign: hyperechoic mucosa internally and hypoechoic muscularis externally.

\section{Treatment}

Based on the possibility of clinical signs worsening and requirement for differential diagnosis, exploratory laparotomy was planned. On surgery, a round multilobuled vascularised mass of approximately two centimetres was identified in the antimesenteric border of descending duodenum (Figure 2), sharing its vascular supply. There was no apparent communication of the mass with the intestinal lumen.

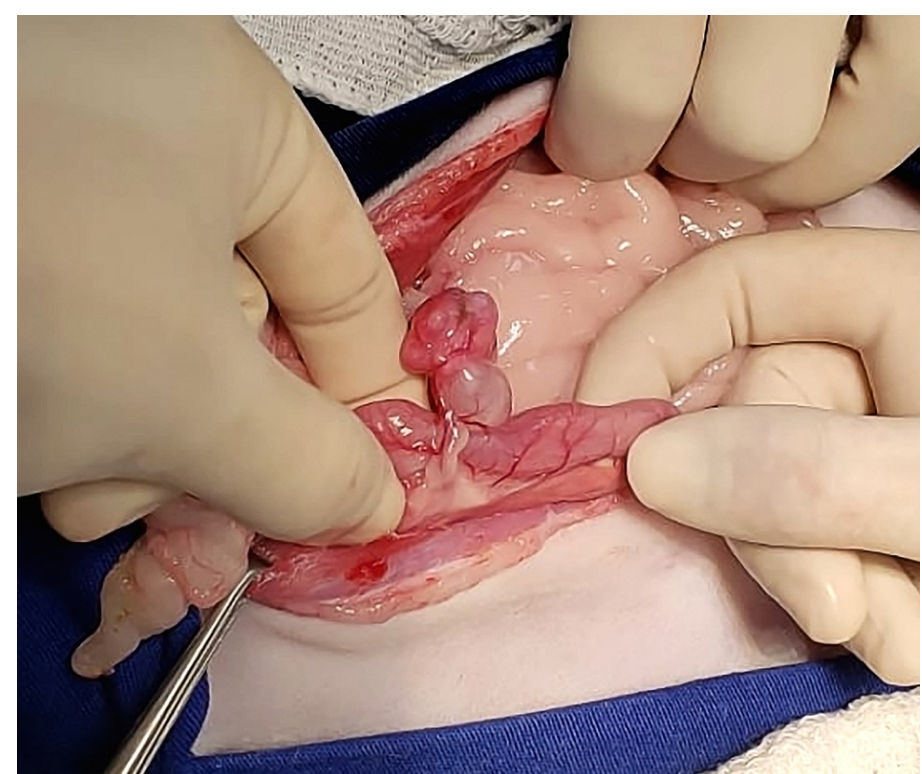

Figure 2 - Intraoperative aspect of the duodenal duplication cyst in the antimesenteric border of descending duodenum. 
Complete excision of the mass from the enteric border was performed and enterorrhaphy was achieved in a single continuous layer with 3-0 poliglecaprone 25 thread. The structure's longitudinal-section revealed multiple lobules (Figure 3).

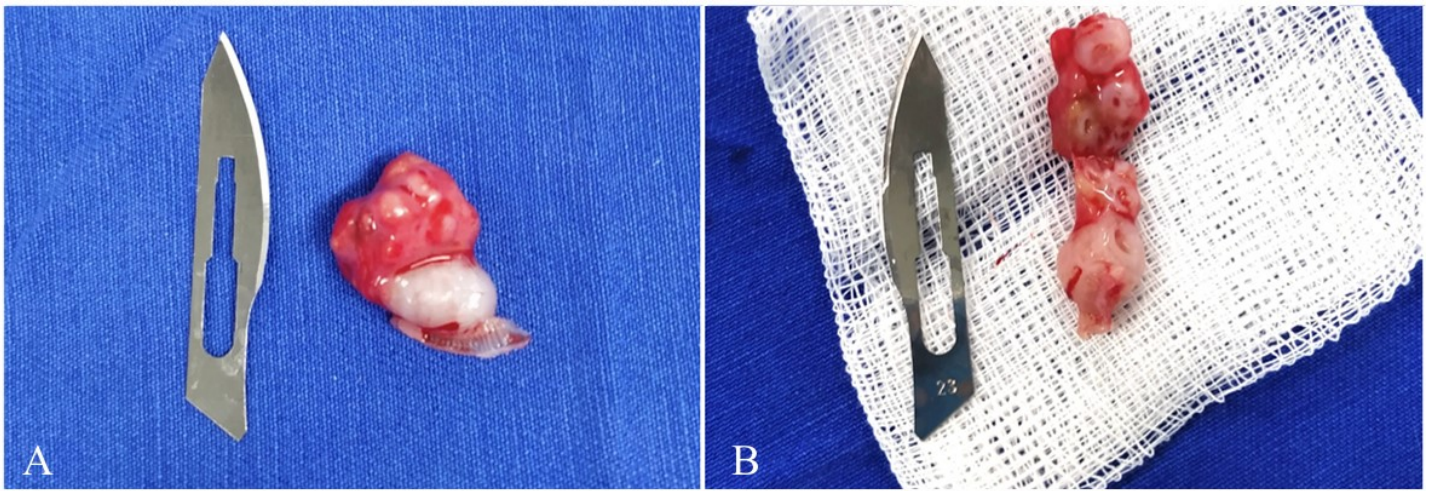

Figure 3 - Resected duodenal duplication cyst. (a) Aspect of mass after surgical removal. (b) Longitudinal-section of excised mass.

Histopathological analysis was compatible with duplication cyst (Figure 4) and there were no signs of malignancy.

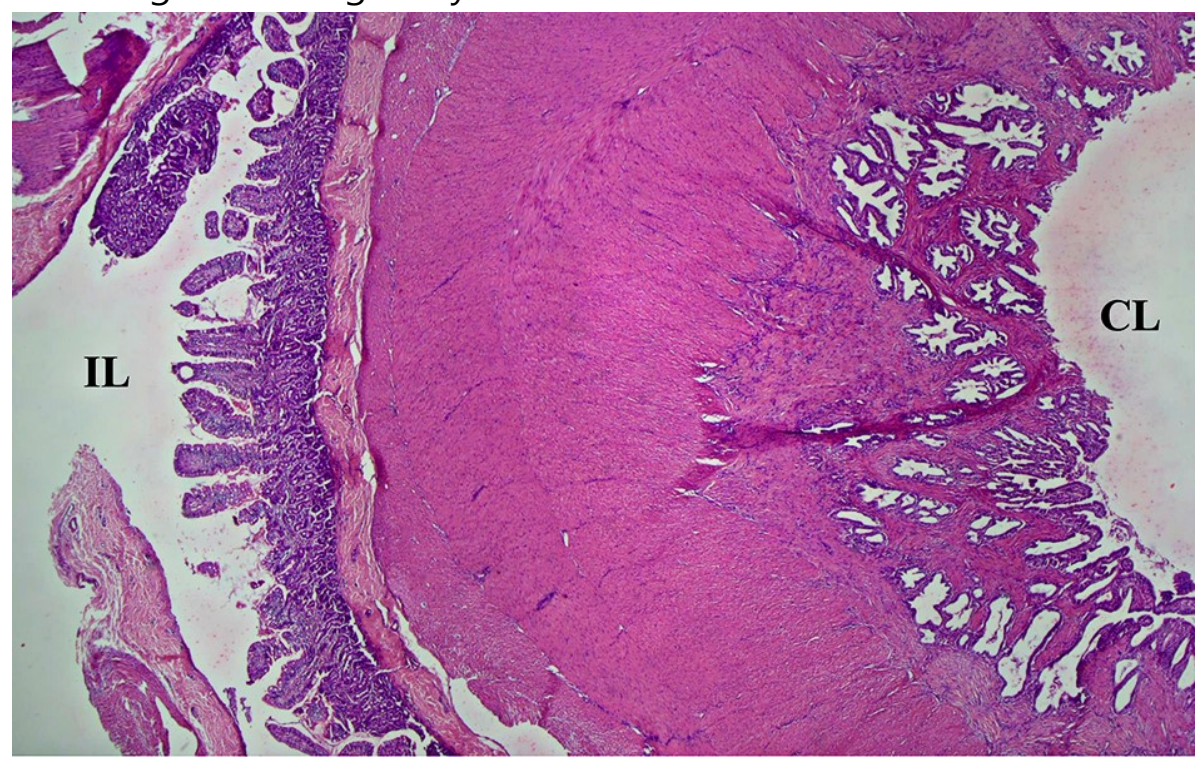

Figure 4 - Histologic appearance of cystic duodenal duplication. Intestinal lumen (IL) on the left and cyst lumen (CL) on the right. Presence of connective tissue, muscular layer, and serosa externally to epithelial lining. $H \& E, x 4$.

\section{Follow up}

The symptoms of emesis, as well as abdominal pain, disappeared after surgical treatment and are still clear at present, 15 months from surgery. 


\section{MATERIAL AND METHODS}

A scoping review was performed using data collected from the PubMed ${ }^{\circledR}$ database and the current case description. Articles included considered histologically confirmed alimentary tract duplications (Radlinsky et al., 2005; Kramer et al., 2007; Kershaw et al., 2008; Parry-Smith et al., 2008; Kook et al., 2010; Bernardé et al., 2014; Doran et al., 2015; Hobbs et al., 2015; Agut et al., 2017; Turner et al., 2019; Carbonell Buj et al., 2020; Fruehwald and Ellison, 2020).

Thirteen gastrointestinal duplication cases in cats were analyzed and one animal had a bi-focal duplication, totalizing fourteen duplications. Variables considered were as follows:

- Age

- Sex

- Breed

- Presenting features

- Anatomic location

- Morphology

- Presence of luminal communication

- Malignant transformation

- Recurrence

\section{RESULTS}

Table 1 gathers data publications related to age, sex, breed, presenting features, anatomic location, morphology, luminal communication, malignancy and recurrence of gastrointestinal duplications in cats described to date.

Age and sex

Kittens (birth to 6 months) affected accounted for approximately 31\% ( $n=4 / 13$ ); junior cats (7 months to 2 years) 31\% ( $n=4 / 13)$; prime cats ( 3 years to 6 years) $15 \%(n=$ $2 / 13)$; mature cats (7 years to 10 years) $15 \%(n=2 / 13)$; and geriatric cats (15 years + ) $8 \%$ $(n=1 / 13)$.

Female cats affected represented for $62 \%(n=8 / 13)$ and male cats $30 \%(n=4 / 13)$. One case $(8 \% ; n=1 / 13)$ had no information about the affected cat's sex. Breed

Domestic shorthair cats (DSH) affected accounted for 69\% $(n=9 / 13)$; Manx $15 \%$ $(n=2 / 13)$ and Siamese $8 \%(1 / 13)$. One case $(8 \% ; n=1 / 13)$ had no information about the affected cat's breed. 


\section{Presenting features}

Including the most cited presenting features, vomiting was present in 6 cases (46\%; $n=6 / 13)$; anorexia and straining to defecate in 3 cases $(23 \% ; n=3 / 13)$; and constipation in 2 cases $(15 \% ; n=2 / 13)$.

\section{Anatomic location}

Oesophagus duplications were present in 14\% $(n=2 / 14)$; duodenum 36\% ( $n=$ $5 / 14)$; jejunum $14 \%(n=2 / 14)$; colon $14 \%(n=2 / 14)$; and rectum $22 \%(n=3 / 14)$.

\section{Morphology and presence of luminal communication}

Cystic duplications with no lumen communication were $93 \%(n=13 / 14)$ and one duplication (7\%; $n=1 / 14)$ was reported to be "segmental", presenting luminal communication.

\section{Malignant transformation}

One duplication evolved to a malignant tumour $(7 \% ; n=1 / 14)$.

\section{Recurrence}

Two duplications presented recurrence $(14 \% ; n=2 / 14)$, whilst twelve $(86 \% ; n=$ 12/14) did not.

Table 1 - Assembled data of alimentary tract duplications in cats showing age and sex, breed, presenting features, anatomic location, morphology, luminal communication, malignancy and recurrence (Supplementary material).

\section{DISCUSSION}

Although the aetiopathogenesis of gastrointestinal duplication cysts remains unclear, theories involving defects in embryogenesis have been postulated, such as the partial twinning theory (Ravitch 1953), the split notochord theory (Bremer 1944), the canalization defects theory (Bentley and Smith 1960) and the environmental factors theory (Favara et al., 1971). No single embryologic mechanism is likely to be considered accurate, since duplications present variable forms (Pant et al., 2012).

In our case, the cyst fulfilled the three anatomic criteria defined by Gross and colleagues (1952) to be considered a duplication since it was (1) associated with the alimentary tract, (2) had a smooth muscle layer and (3) had gastrointestinal-like epithelium according to histopathology analysis. Only twelve other reports have been found in literature describing similar alimentary tract duplications in cats (Radlinsky et al., 2005; Kershaw et al., 2008; Parry-Smith et al., 2008; Kook et al., 2010; Bernardé et al., 2014; Doran et al., 2015; Hobbs et al., 2015; Agut et al., 2017; Kramer et al., 2017; Turner et al., 2019; Carbonell Buj et al., 2020; Fruehwald and Ellison 2020). 
Cerquetella and colleagues (2015) described recurrent constipation and abdominal pain as a result of a possible colonic duplication cyst in a five-year-old domestic shorthair cat. Considering that histopathology, in that case, was not conclusive; the report was not included in this scoping review.

Young cats affected by duplications accounted for approximately $62 \%(n=8 / 13)$ with most cases occurring in kittens from zero to 6 months old (Parry-Smith et al., 2008; Bernardé et al., 2014; Fruehwald and Ellison 2020) and junior cats from 7 months to 2 years (Radlinsky et al., 2005; Kramer et al., 2007; Doran et al., 2015; Agut et al., 2017) which is compatible to the age of the cat in the current case (2 years old). Human reports have analogous results with duplications being mostly diagnosed in infants and children (Stern and Warner 2000; Seeliger et al., 2012). Only one case was a geriatric cat that presented malignant transformation of a duodenal duplication cyst (Hobbs et al., 2015), which has also been reported in humans (Seeliger et al., 2012).

Symptoms observed in previous reports were related to the duplication's anatomic site. Oesophagus cysts coursed with dyspnea (Bernardé et al., 2014) and regurgitation (Doran et al., 2015); small intestine cysts led mainly to recurrent vomiting (Kershaw et al., 2008; Parry-Smith et al., 2008; Bernardé et al., 2014; Hobbs et al., 2015; Agut et al., 2017), even though one case was an asymptomatic cat (Radlinsky et al., 2005); and large intestine duplications caused, mostly, constipation and straining to defecate (Kramer et al., 2007; Kook et al., 2010; Turner et al., 2019; Carbonell Buj et al., 2020; Fruehwald and Ellison 2020). In the present case, the cat presented recurrent emesis and mild epigastric pain but no other symptoms.

Duodenal duplications are known to be rare in humans and account for approximately $5 \%$ of enteric duplications (Arbell et al., 2002). Meantime, it is one of the most common locations of duplications in cats (approximately 36\%; $n=5 / 14$ ) (ParrySmith et al., 2008; Bernardé et al., 2014; Hobbs et al., 2015; Agut et al., 2017) and this work reports the fifth case known in literature thus far.

Most studies have described duplications in cats as cystic with an independent lumen (93\%, $n=13 / 14$ ) (Radlinsky et al., 2005; Kershaw et al., 2008; Parry-Smith et al., 2008; Kook et al., 2010; Bernardé et al., 2014; Doran et al., 2015; Hobbs et al., 2015; Agut et al., 2017; Kramer et al., 2017; Turner et al., 2019; Carbonell Buj et al., 2020), similarly to our case cyst's features. In humans most duplications are cystic with no lumen communication, whereas some are cylindrical structures that can or not have direct intestinal communication (Bhatt et al., 2020). More recently, a case of a segmental colonic 
duplication with lumen communication was reported in a female kitten (Fruehwald and Ellison 2020).

Multiple level enteric duplications are rather uncommon but have been reported to occur in humans, with oesophageal duplication associated with small bowel duplication being the most frequent combination (Hur et al., 2007). Interestingly, one cat report showed a comparable presentation (Bernardé et al., 2014). Thus, once the duplication is diagnosed, other duplications should be sought; therefore, imaging methods should be contemplated (Nebot et al., 2018).

Ultrasound evaluation is the most used imaging method for diagnosis (Nebot et al. 2018) since it shows inner hyperechoic and outer hypoechoic layers - double-wall sign or muscular rim sign - relatively specific of duplication cysts (Hur et al., 2007; Agut et al., 2017), which was present in our cat's ultrasound evaluations. The technique has limitations once it is operator and patient dependent and, occasionally, US alone is not able to determine the origin of the lesion and presence of lumen communication. Hence, contrast radiography and computed tomography (CT) may complement evaluation (Agut et al., 2017).

Moreover, some factors associated to size, location, type, mucosal pattern and presence of complications may lead to different imaging findings of duplication cysts. It is important to consider bowel obstruction, intramural haematoma, intramural tumours, abscess, pancreatic pseudocysts, choledochal cysts and neoplasia as differential diagnosis (Agut et al., 2017; Nebot et al., 2018).

Exploratory laparotomy with total excision of the enteric duplication cyst is the standard treatment (Hobbs et al., 2015; Turner et al., 2019) and it was suitable in the current case, since there were no signs of recurrence and the cat recovered well after procedure. Recurrence has been reported in two previous cases (Kramer et al., 2007; Hobbs et al., 2015). In humans, minimally invasive techniques - such as laparoscopy - are also proving to be effective on complete resection of intestinal duplications (Górecki et al., 2015).

\section{CONCLUSION}

To summarize, it is essential for the small animal practitioner not to overlook alimentary tract duplications in the differential diagnosis of young cats with chronic vomiting and cystic intestinal masses diagnosed by US evaluation. As far as we are concerned, this is the first scoping review about alimentary tract duplications in cats, as well as the first case description to occur in Latin America. 


\section{Acknowledgements}

The authors thank the cat owners who authorized the use of the data of their animal in this study and the lab Vetpat for its promptness in providing microscopic images of the cyst. We are also grateful to Gerry O'Shea for the English revision and Frederico Siciliano for the image adjustments.

\section{REFERENCES}

AGUT, A.; CARRILLO, J.D.; MARTÍNEZ, M. et al. Imaging diagnosis - radiographic, ultrasonographic and computed tomographic characteristics of a duodenal duplication cyst in a young cat. Veterinary Radiology Ultrasound, v.59, n.3, p. E22-E27, 2017.

ARBELL, D.; LEBENTHAL, A.; BLASHAR, A. et al. Duplication cyst of the duodenum as an unusual cause of massive gastrointestinal bleeding in an infant. Journal of Pediatric Surgery, v.37, n.E8, p. 8-9, 2002.

BENTLEY, J.F.R.; SMITH, J.R. Developmental posterior enteric remnants and spinal malformations. Archives of Disease in Childhood, v.35, n.1, p. 76-86, 1960.

BERNARDÉ, A.; FORGET, J.; BERNARD F. Multiple level enteric duplication cysts in a cat. Revue Vétérinaire Clinique, v.49, n.1, p. 31-35, 2014.

BHATT, K.; MANGUKIYA, D.; PAREKH, K.A. Mesenteric enteric duplication cyst communicating with jejunum in adolescent: communicating jejunal duplication cyst. Journal of Case Reports, v.10, n.1, p. 5-7, 2020.

BREMER, J.L. Diverticula and duplications of the intestinal tract. Archives of Pathology, v.38, n.1, p. 132-140, 1944.

CARBONELL BUJ, E.; BILLET, J.P.; VANEL, M. et al. Rectal duplication in an adult cat: a novel transanal cirurgical approach. Journal of Feline Medicine and Surgery Open Reports, p. 6, 2020.

CERQUETELLA, M.; TAMBELLA, A.M.; LAUS, F. et al. Colonic cyst in a cat presenting recurrent constipation and abdominal pain. Tierärztliche Praxis Ausgabe K, v. 43, p. 345349, 2015.

DORAN, I.C.P.; DAWSON, L.J.; COSTA, M. Surgical resolution of an oesophageal duplication cyst causing regurgitation in a domestic shorthair cat. Journal of Feline Medicine and Surgery Open Reports, p.1-4, 2015.

FAVARA, B.E.; FRANCIOSI, R.A., AKERS, D.R. Enteric Duplications Thirty-seven cases: A vascular theory of pathogenesis. The American Journal of Diseases of Children, v.122, n.1, p. 501-506, 1971.

FRUEHWALD, C.; ELLISON, G. Successful surgical correction of congenital colonic duplication and anogenital cleft in a cat. Journal of the American Animal Hospital Association, v.56, n.3, p. 170-174, 2020.

GÓRECKI, W.; BOGUSZ, B.; ZAJĄC, A. et al. Laparoscopic and laparoscopy- assisted ressection of enteric duplications cysts in children. Journal of Laparoscopic \& Advanced Surgical Techniques, v.25, p. 838-840, 2015. 
GROSS, R.E.; HOLCOMB, G.W.; FARBER, S. Duplications of the alimentary tract. Pediatrics, v.9, n.1, p. 449, 1952.

HOBBS, J.; PENNINCK, D.; LYONS, J. Malignant transformation of a duodenal duplication cyst in a cat. Journal of Feline Medicine and Surgery Open Reports, p. 1-3, 2015.

HWANG, T.S.; JUNG, D.I.; KIM, J.H. et al. Non-communicating small intestinal duplication in a dog: a case report. Vet Med-Czech Journal, v.62, p. 516-521, 2017.

HUR, J.; YOON, C.S.; KIM, M.J. et al. Imaging features of gastrointestinal tract duplications in infants and children: from oesophagus to rectum. Pediatric Radiology Journal, v.37, n.7, p. 691-699, 2007.

KERSHAW, O.; DEPPENMEIER, S.; GRUBER, A.D. Multiple cystic intestinal duplications in a cat. Journal of Veterinary Pathology, v.45, p. 188-190, 2008.

KOOK, P.H.; HAGEN R.; WILLI B.; et al. Rectal duplication cyst in a cat. Journal of Feline Medicine and Surgery, v.12, p. 978-981, 2010.

KRAMER, A.; KYLES, A.E.; LABELLE, P. Surgical correction of colonic duplication in a cat. Journal of the American Animal Hospital Association, v.43, p. 128-131, 2007.

NEBOT, C.S.; SALVADOR, R.L.; PALACIOS, E.C. et al. Enteric duplication cysts in children: varied presentations, varied imaging findings. Insights into Imaging, v.9, p. 1097-1106, 2018.

PANT, N.; GROVER, J.K.; MADAN, N.K. et al. Completely isolated enteric duplication cyst associated with a classic enterogenous duplication cyst. Journal of Indian Association of Pediatric Surgeons, v.17, n.2, p. 68-70, 2012.

PARRY-SMITH, P.; CZERWINSKA, M.; KRUDEWIG, C. Duodenal duplication cyst in a young cat. Veterinary Records, v.162, 826-827, 2008.

RADLINSKY, M.A.G.; BILLER, D.S.; NIETFELD, J. et al. Subclinical intestinal duplication in a cat. Journal of Feline Medicine and Surgery, v.7, p. 223-226, 2005.

RAVITCH, M.M. Hindgut duplications - Doubling of colon and genital urinary tracts. Annals of Surgery, v.137, n.1, p. 599-601, 1953.

SEELIGER, B.; PIARDI, T.; MARZANO, E. et al. Duodenal duplication cyst: a potentially malignant disease. Annals of Surgical Oncology, v.19, n.12, p. 3753-3754, 2012.

STERN, L.E.; WARNER, B.W. Gastrointestinal duplications. Seminars in Pediatric Surgery, v.9, p. 135-140, 2000.

TURNER, H.S.; BERKE, K.; BILLER, D.S. et al.Rectal duplication cyst in a cat: a case report and literature review. Israel Journal of Veterinary Medicine, v.74, n. 1, p. 32-38, 2019. 